\title{
コンジョイント分析の交通機関選択モデルへの 適用に関する諸問題 \\ SOME PROBLEMS ON CONJOINT ANALYSIS TO APPLY THE MODE CHOICE MODEL
}

\author{
湯沢昭*・須田熙**・高田一尚*** \\ By Akira YUZAWA, Hiroshi SUDA and Kazunao TAKADA
}

\begin{abstract}
In this paper, we discuss the Decision-making of Individual behavioral based on the Conjoint analysis. The Conjoint analysis is the approach that applies the theory of the Conjoint-measurement on the mathematical psychology of consumer preference. The Conjoint analysis can estimate the individual partworth that reproduce the ordered relation from given Rank-ordered data.

This paper takes up the Conjoint analysis based on the stochastics utility theory, that is, extending the Conjoint-logit model. We applied the Conjoint-logit model to the decision making of modal choice for commutation trip and confirmed that the Conjoint-logit model becomes a very useful method to the decision making of individual behavioral.

Keywords : decision making, conjoint analysis, logit model, SP data
\end{abstract}

\section{1. 序論}

意思決定とは，種々の代替案の中からある決定基準に 基づいて最良なるものを選択することであり ${ }^{1)}$ ，その決 定基準の違いによりいろいろなモデルが定式化されてい る. 土木計画の中で最も一般的に使用されているものの 1 つに非集計モデル (Disaggregate Model) がある.こ のモデルは当初計量生物学の分野で先行していたもの が, 1970 年代に経済学の分野で実用的な研究が行われ, 現在までに労働力市場や企業立地等の多くの研究成果が 報告されている.特に McFadden らの研究により交通需 要の理論が経済学の消費者行動の理論上に明確に位置づ けされ，大きな進展をみて今日に至っている2).

非集計モデルは3), 個人が意思決定の単位であり, 個人 は選択可能なものの中から最大の効用を与える選択肢を 選ぶという合理的選択行動をとると仮定する。つまり個 人属性や選択環境が類似している集団で，かつ全員が効 用最大化という基準に従って行動すれば，その集団は全

\footnotetext{
* 正会員 工博 東北大学助手 工学部土木工学科 ( ( 980 仙台市青葉区荒巻字青葉)

** 正会員 工博 東北大学教授 工学部土木工学科 (同上)

*** 正会員 工修 東日本旅客鉄道( $($ 侏)

（厂100 千代田区丸ノ内 $1-6-5$ )
}

く同じ行動をとるとしている.この場合，観測されない 属性により誤差項に一定の分布形を仮定することによ $\eta$, Logit モデルや Probit モデルが導出されるのは周知 のとおりである.しかし, 問題となるのはどのようにし て母集団の中から類似している集団を分離するか，また 分離された集団の各個人が本当に同じ意思決定基準を有 しているのか. つまり非集計モデルの問題の 1 つは個人 間の選択肢, 属性, および属性のウェイトの差をセグメ ント間でしか評価しきれないところにある。

次に意思決定モデルを用いるデータにより分類すると 大きく 2 つに分けられる. 1 つは, 行動結果デー夕 (Revealed Preference，以下 RP デー夕とする）に基づ くものと, 本研究でも採用している選好意識データ (Stated Preference, 以下 SP データとする)を用いる方 法である. 本論文で研究対象としている交通機関選択問 題に対しては, 従来 RPデー夕を適用する方法が一般的 であったが, SPデー夕を用いる研究も行われている。た とえば佐藤・五十嵐 ${ }^{4}$ による空港アクセスにおける交通 機関分担モデルは, SP データを用いた先駆的な研究で あり，また河上・広畠 ${ }^{5}$ は, 利用者の交通サービス特性に 対する主観的評価を明示的に取り扱うことにより理論を 展開している. Ben-Akiva, Morikawa, T. ${ }^{6}$ は, RP デー 夕と SP デー夕を統合することにより，その両方の長所 
を引き出し，モデルの精度の向上を図っている。

本研究で採用するコンジョイント分析は，まさに SP データを用いた分析手法である.ここでコンジョイント 分析とは, 数理心理学におけるコンジョイント測定法 (Conjoint Measurement) の考え方をマーケッティン グ・リサーチの分野において消費者選好の測定に応用し ようという試み全体を総称したものである。このコン ジョイント测定法とは7)「多次元な要因の組合せに対す る何らかの順序関係が与えられたときに，そこから個々 の要因の効果を測定する個別尺度 (Partworth)，および 与えられた順序関係を再現するすべての要因の同時結合 尺度 (Conjoint Scale) をある定められた結合ルールの もとで, 同時に見出すことである」. そのなめの手法とし ては, Kruskalによる MONANOVA ${ }^{8)}$, Srinivasan, Shockerによる LINMAP ${ }^{9}$ が代表的なものである.これ らはいずれも確定論的な方法であり, 確率論的手法とし ては，コンジョイント分析に Logit モデルの考え方を導 入した小川7), 片平 ${ }^{10)}$, Ogawa $^{11)}, \mathrm{McFadden}^{12)}$, Chapman ${ }^{13)}$ の研究が挙げられる.これらはいずれもマー ケッティング・リサーチの分野に扔ける消費者選好モデ ルについての研究であるため，コンジョイント分析を交 通機関選択の意思決定問題に適用するためには, いくつ かの解決すべき問題点がある.

本研究の目的は，コンジョイント分析に Logit モデル を適用し，以下に挙げる問題点について考察を行い，そ の結果を交通機関選択モデルに応用し，コンジョイント 分析の有効性について検討を行うものである.

(1) Conjoint-Logit モデルの解の不定性問題

(2) コンジョイント分析用のデータ収集の問題

(3) コンジョイント分析用のデー夕作成の問題

(4) 選択の深さの問題

(5) Conjoint-Logit モデルによる予測の問題

\section{2. コンジョイント分析への Logit モデルの 適用}

\section{（1）個人の意思決定に関する従来研究}

本研究で詨象としている意思決定とは，選択肢（また は代替案）が複数の属性（あるいは評価指標）で定義さ れている多属性問題である．個々の選択肢はそれが仮想 的なものでも実際の市場に出ているものでもかまわない が，属性を用いて意思決定者に対し客観的に記述される 必要がある.このように提示された選択肢に対し, 個人 がどのような意思決定基準をもとに判断を行っているか を分析することが本研究の目的であり, 方法論的には大 きく 2 つに分類される。1つは補償型意思決定モデルで あり，もう 1 つは非補償型である。

補償型とは, 属性間の補償関係を許すもので, 各属性
に重みを考慮し効用等の一次元尺度に変換するものであ る.この代表的手法としては, 効用理論に基づく各種手 法が挙げられる。しかし, 個人の意思決定基準が必ずし も複数の属性を同時に考慮しているものではないという 立場から優越基準, 満足基準, または順番基準等の非補 償型モデルの研究も行われている. これらは, 特に属性 が数量化されていない場合には有効である.

しかし，そのいずれの基準に従って個人が行動してい るかを第三者が評価することは非常に困難である，島崎 $ら^{14)}$ による判断基準の序列化に基づく方法は, 順番基準 により交通機関の選択を行い，かつ選択行動を同質化さ せることにより，母集団のセグメント化を困っている. この方法は, 従来の非集計モデルよりも個人差が明確に なるが, すべての個人が順番基準により意思決定を行っ ているかの問題もある.

本研究の中心的課題である個人行動の意思決定の方法 としては，コンジョイント分析を適用する。これは与え られた（または自分で想定した）選択肢に対し，何らか の価值基準に基づき順序関係を設定し，その順序関係を 再現することにより，各属性の重みを個人別に推定しよ うとする個人モデルである。したがって, 基本的には補 償型モデルの範疇に属するが, 評価する属性を絞り込む ことにより，非補償型モデルにも対応可能である．また この手法は個人を対象とした分析であるため, 個人によ る選択肢，属性，および属性の重みの差を直接評価する ことができるという特徴を有している。

\section{(2) Conjoint-Logit モデルの作成}

コンジョイント分析は, プロフィール（選択肢）とよ ばれる仮想的製品/サービスを選好の对象として, 物理 的, 機能的属性と選好との関係を測定, 分析しようとい うものである.この場合, 属性数とその水準により選択 肢の数が膨大となるため, あらかじめ実験計画法を用い ることにより選択肢数を減少させておく必要がある.

次に分析者は，属性の組合せである選択肢集合を消費 者に提示し, 消費者は自分の価値判断に基づき提示され た選択肢に序列を付ける。これにより得られる選好デー 夕は, 通常のコンジョイント分析においては $N$ 個の選択 肢に対する全順序デー夕を用いるが，必ずしも消費者が すべての選択肢に序列を付けるわけではない，いま，個 人が順序付けした選択肢の数（選択の深さという）を $n$ とすると，おのおのの選択肢より得られる効用の序列は 式(1)のようになる.

$$
U_{1} \geqq U_{2} \geqq \cdots \cdots \geqq U_{n}
$$

また, 各選択肢の効用 $U_{j}$ は, マーケッティング・リサー チの分野においては一般的に次のように表現される.

$$
U_{j}=\sum_{i} \sum_{k} \theta_{i k} X_{i k j}+\sum_{i} \theta_{i} X_{i j}
$$


ここに, $U_{j}$ : 選択肢 $j$ の全体効用

$X_{i k j}$ : 選択肢 $j$ において属性 $i$ が第 $k$ 水準の とき 1 ，それ以外は 0

$\theta_{i k}:$ 属性 $i$ の水準 $k$ に対する重み

$X_{i j}:$ 選択肢 $j$ に扔ける属性 $i$ の值

$\theta_{i}:$ 属性 $i$ の重み

したがって，コンジョイント分析の目的は式(1)の条 件を満足するような式 $(2)$ のパラメーター $\theta_{i k}, \theta_{i}$ を求 めることに帰着する。このパラメーターを求めるための アルゴリズムとして，前述したように MONANOVA， LINMAP，および Logit モデルがある。本論文では，確 率効用理諭に基づいた Logit モデルを採用する. 式 (2) に示した選択肢 $j$ の効用 $\left(U_{j}\right)$ が, 確定項 $\left(V_{j}\right)$ と確率項 $\left(\varepsilon_{j}\right)$ の和であり, さらに確率項の分布形に二重指数分布 を仮定することにより多項 Logit モデルが導出される のは周知のとおりである（式 $(3))$.

$$
P_{j}=\exp \left(\omega V_{j}\right) / \sum_{j} \exp \left(\omega V_{j}\right)
$$

次に式 ( 1 ) で示した各選択肢の序列が得られる確率を 式(4)のように考える.

$$
P(1,2, \cdots, n)=P\left(1 \mid J_{1}\right) \cdot P\left(2 \mid J_{2}\right) \cdots P\left(n \mid J_{n}\right)
$$

式 (4)の右辺, たとえば $P\left(1 \mid J_{1}\right)$ は選択肢 $n$ 個の中か ら 1 番目の選択肢が選ばれる確率であり, $P\left(2 \mid J_{2}\right)$ は 1 番 目の選択肢を除いた残りの中から 2 番目の選択肢が選ば れる確率を表現している。したがって，式（4)はおのお のの選択肢が選ばれる同時確率を表わしていることにな る. 式( 3 )，式(4)により

$$
P(1,2, \cdots, n)=\prod_{h=1}^{n}\left\{\exp \left(\omega V_{h}\right) / \sum_{j=h}^{n} \exp \left(\omega V_{j}\right)\right\}
$$

となり，効用の確定項 $\left(V_{j}\right)$ に式 (2)を代入し，未知パラ メーター $\theta$ の関数とみなすことにより, 式 $(5)$ は尤度関 数となる. したがって，パラメーターの推定は最尤推定 法を適用することにより求めることが可能である．式 （5）は順序付けデー夕に Logit モデルを適用したもの であり，小川7は，従来の集計型モデルである Logit モデ ルと区別するために Conjoint-Logit モデルとよび，片 平15)はRank-Logitとしている．また藤原ら ${ }^{16)}$ の意識 データの交通機関への適用では Ordered-Logit モデル としているが，これは非集計モデルへの適用となってい る.このように研究者, 研究分野によりその名称は統一 されていないが, 本研究は個人モデルを対象としており, 従来の集計型のモデルである Logit モデルと区別する ため，小川と同様にConjoint-Logit モデルとよび，その 集計型を非集計 Conjoint-Logit モデルとする.また交通 計画の分野で用いられている個人デー夕を用いたLogit モデルは従来どおり非集計 Logit モデルとよぶ.

\section{Conjoint-Logit モデルの交通機関選択モ デルへの適用上の問題}

\section{（1）Conjoint-Logit モデルの解の不定性問題}

Conjoint-Logit モデルは, 個人の選好デー夕に基づい て個人別のパラメーター $\theta$ を求めることが目的である ため, 個人デー夕を繰り返し収集し，そのデー夕量が統 計的検定に耐之得るためには十分なる量を必要とする. また個人モデルゆえの問題もある。そのなかで特に問題 となるのが「矛盾のない序列」の場合である。これは与 えられた順序関係が加法的表現と矛盾しない場合には, 解が発散しパラメーター $\theta$ を求めることができないと いうものである．たとえば式（5)において $V_{j}=\theta_{1} X_{1 j}$ と し， $n=2$ とすると

$$
\begin{aligned}
& P=\frac{e^{\omega V_{1}}}{e^{\omega V_{1}}+e^{\omega V_{2}}}=\frac{e^{\omega\left(\theta_{1} X_{11}\right)}}{e^{\omega\left(\theta_{1} X_{11}\right)}+e^{\omega\left(\theta_{1} X_{12}\right)}} \\
& =\frac{1}{1+e^{\omega \theta_{1}\left(X_{12}-X_{11}\right)}}
\end{aligned}
$$

となる.ここで「矛盾のない序列」とは， $X_{11}>X_{12}$ の場 合であり，そのときには式 $(6)$ の分母 $\left(X_{12}-X_{11}\right)$ の值は 負になることがわかる。つまり，式（6）の尤度を最大に

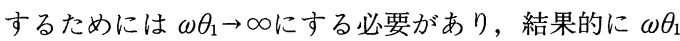
の值は発散することになる。また効用関数を式 (2)のよ うに線形とした場合には， $\omega$ と $\theta$ を分離することもでき ない.この問題に対処するためには 2 通りの方法が考え られる. 1 つは，全サンプルが同じパラメーターをもつ ものとしてすべてのデータをプールしたうえでパラメー ターの推定を行うものであり，この方法が非集計 Conjoint-Logit モデルである.もう 1 つの方法は， $\theta$ を基準 化し, 誤差分散 $\left(\pi^{2} / 6 \omega^{2}\right)$ のパラメーター $\omega$ の值を外か ら与える方法である。いま, $\theta$ を基準化し，式 (3)の $\omega V_{j}$ $=\omega \sum_{i} \theta_{i} X_{i j}$ を次のように変形する.

$$
\omega V_{j}=\omega \sum_{i} \widetilde{\theta}_{i} X_{i j}
$$

ただし, $\omega \theta_{i}=\omega_{0} \tilde{\theta}_{i}, \sum_{i} \tilde{\theta}_{i}{ }^{2}=1, \omega_{0}:$ 外から与えられた誤 差分散のパラメーター.

式 $(7) て ゙ \omega_{0}$ は $\theta_{i}$ の大きさを定めるスケールパラメー 夕ー, $\tilde{\theta}_{i}$ が各属性間の相対的重要度となり,「矛盾のない 序列」の場合には $\omega_{0}$ の值により式 ( 3 )の $P_{j}$ は次のよj になることがわかる.

$$
\left.\begin{array}{ll}
\omega_{0}=\infty \text { の場合 } & P_{1}=1, P_{2}=\cdots=P_{n}=0 \\
\omega_{0}=0 \text { の場合 } & P_{1}=P_{2} \cdots=P_{n}=1 / n
\end{array}\right\}
$$

式 ( 8 ) より， $\omega_{0}$ の值は各選択肢間の相対的選択確率に大 きな影響を与えていることがわかる。

Conjoint-Logit モデルの目的が単に個人の序列デー 夕を再現するような $\theta$ を決定するだけであれば $\omega_{0}=1$, $\Sigma \tilde{\theta}_{i}{ }^{2}=1$ とすることにより式 (5)の尤度関数を解くこ 
とはできる.しかし，それは式 $(1)$ の選択肢の効用の序 列を再現するだけであり, 式 (3) で示した各選択肢の選 択確率を求めることができないのは明らかである.した がって個人の選択確率 $P_{j}$ を求めるためには， $\omega_{0}$ の值を 推定することが不可欠である.

片平 ${ }^{10)}$ はこの問題の解決策として, 式 $(5)$ の尤度関数 を $\omega=1, \sum \theta_{i}{ }^{2}=1$ とした条件付問題として $\theta$ の值を決 定し, 次に全サンプルをプールしたうえで $\omega$ の值を決定 している.つまり $\theta$ の推定にあたっては個人間の異質性

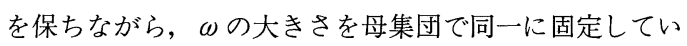
る. しかし， $\omega$ の值を固定することは, 式 $(8)$ からも明 らかなように各選択肢の相对的選択確率を固定すること になるし,また個人モデルである Conjoint-Logit モデル の特徴が薄れてしまう可能性もある.

本論文では, 誤差分散のパラメーター $\omega_{0}$ を以下に示 す方法を用いて推定した. すなわち個人が利用可能とし た選択肢（交通手段の組合せ）の選択確率は明らかに零 以上であり，1番目の序列の選択肢の確率が最も高く, 選好序列が低くなるほどその確率は小さくなる，ここで 個人は 1 番目の選択肢とそれ以外の選択肢との相対的選 択確率を知覚しているものと仮定する. したがって，第 1 番目に序列された選択肢の選択確率 $\left(P_{1}\right)$ が与えられ たとした場合,

$$
P_{1}=\exp \left(\omega_{0} V_{1}\right) / \sum_{j} \exp \left(\omega_{0} V_{j}\right)
$$

となり, その両辺の対数を取り, 次のように変形する.

$$
\begin{gathered}
\omega_{0} V_{1}-\ln \left\{\sum_{j} \exp \left(\omega_{0} V_{j}\right)\right\}-\ln \left(P_{1}\right)=0 \\
\text { ただし, } 1>P_{1}>1 / n
\end{gathered}
$$

式( 7 )より $V_{j}=\sum \tilde{\theta}_{i} X_{i j}, \sum \tilde{\theta}_{i}{ }^{2}=1$ であるが, 改めて $\omega_{0} \tilde{\theta}_{i}=\theta_{i}$ とおくと式 $(10)$ は $\theta$ みの関数となる. した がって, 数值計算により $\theta_{i}$ の值を求め, $\Sigma \theta_{i}{ }^{2}=\omega_{0}{ }^{2}$ とす ることにより $\omega_{0}$ を推定する. 当然, $P_{1}=1$ の場合は, 式 (8) からも明らかなように $\omega_{0} \rightarrow \infty$ となる可能性がある が, $P_{1}<1$ であるためその解を求めることができる。これ は小サンプルにおけるパラメーター $\theta$ の特異な動きを, その基準化後に $\tilde{\theta}_{i}$ にではなく， $\omega_{0}$ に帰することにする ものである.その結果,「矛盾のない序列」においては, $\omega_{0} \rightarrow \infty に よ \eta \varepsilon_{j}$ の分散を零に近づけようとするもので ある.したがって, 式 $(5)$ の $V_{j}$ を線形関数とすると最大 化問題は次のようになる.

$$
L(\theta)=\sum_{h=1}^{n}\left[\omega_{0} V_{h}-\ln \left(\sum_{j=h}^{n} \exp \left(\omega_{0} V_{j}\right)\right] \rightarrow \operatorname{Max}\right.
$$

Sub. to $V_{j}=\sum_{i} \tilde{\theta}_{i} X_{i j}, \sum_{i} \tilde{\theta}_{i}{ }^{2}=1$

式(11)は, Fletcher-Powell 法等の数值計算により解を 求めることができる.

\section{（2）コンジョイント分析用データ収集の問類}

コンジョイント分析に用いるデータは, 式 (2)に示し たように $X_{i k j}$ (選択肢 $j$ において属性 $i$ が第 $k$ 水準のと き 1 , それ以外は 0 ) と $X_{i j}$ (選択肢 $j$ における属性 $i$ の 值)の 2 種類ある. この場合 $X_{i k j}$ は属性数と水準の数に よりプロフィール数が膨大な数になることがわかる．た とえば属性数が 5 ，おのおのの水準が 3 の場合のプロ フィール数は， $5^{3}=125$ 個になる．したがってすべての プロフィールを提示し，その序列を各個人に対し求める のは実際上不可能となるため，実験計画法による直交配 置を用いてプロフィール数を減少させるのが一般的な方 法である。

このようにコンジョイント分析は, 本来マーケッティ ング・リサーチの分野における消費者選好測定の手法と

して研究されてきたため，土木計画における交通機関選 択や住宅立地における個人の意思決定問題に適用する場 合，属性と選択肢の設定に注意する必要がある．属性の 設定は非集計モデル等で多くの研究報告があるためあま ク問題はないが，選択肢の集合をどのように各個人に提 示し，序列デー夕を収集するかが問題となる．1つの方 法としては，マーケッティング・リサーチの分野と同様 にすべての選択肢（または直交配置後の選択肢）を提示 し，その中から選択可能なところまでの序列を付けても らう方法（以下データ A とする）と，もう 1 つは選択肢 の序列とその属性の值を回答してもらう方法や, 属性值 のみ後で客観デー夕を使用する方法もある（以下，デー タ B とする).

前者の方法は，前述したように現在市場にでていない ものに対しても評価を行うことが可能であるが，提示し た属性によりそれぞれの選択肢が客観的に表現されなけ ればならない.このデータ収集の例としては，佐藤ら ${ }^{4} に$ よる空港アクセスにおける交通機関分担モデルの研究が ある. 後者の方法としては，たとえば交通機関の選択の ように各交通機関の利用しやすい順番（または利用した い順番）に序列付けを行い，各選択肢の属性の值は客観 データや主観データにより別途作成する方法である.こ の場合には，提示した以外の選択肢があってもかまわず （個人に選択肢を作成してもらう），あらかじめ提示する 選択肢の数を減らすことが可能である。このいずれの デー夕収集方法を採用するかは当然対象とする問題によ ク異なる.しかし, 最終的に求めるものは, 個人の各属 性の重み $(\theta)$ であるため，そのパラメーターの時間的安 定性を考慮すると大きく市場が変化するような場合は前 者の方法が，逆に市場にそれほどの構造変化が伴わない 場合には後者の方法が適していると考えられる.

（3）コンジョイント分析用データ作成の問題

前節ではコンジョイント分析用に収集されたデー夕形 
式にはデータ A とデータ B の 2 種類があることを述べ た.マーケッティング・リサーチの分野では一般的にデー 夕Aの形式を採用し，そのデータを式(2)に代入し，パ ラメーター $\theta$ を前述した種々の方法で求めている．たと えば Conjoint-Logit モデルを用いてパラメーターを推 定する場合, 非集計モデル(セグメント別にパラメーター を推定）では最尤推定量の漸近的性質を利用した統計的 検定ができるため，その有意性の検定により属性の絞り 込みが可能である. しかし，個人レベルのパラメーター の推定では統計的検定による属性の絞り込みは困難であ るため, 本論文ではパラメーターの符号により属性の選 択基準を考える．つまり，属性の值とその合成変数であ る全体効用との関係からパラメーターの符号に矛盾がな いかを検討するものである.しかし，デー夕 Aのように 属性ダミ一変数の場合には，目的変数である全体効用に 対し，各属性のパラメーターの符号が一意的に正または 負になるかを判断するのは困難である．したがって，本 研究ではデータ B の形式を採用し, 各属性は基本的に連 続変数とし，ダミ一変数を使用する場合も，その符号の 基準が明らかなように設定する。これは，前述したよう に小サンプルにおけるパラメーターの特異な動きを，そ の基準化後の $\tilde{\theta}_{i}$ ではなく， $\omega_{0}$ に帰しており， $\tilde{\theta}_{i}$ は属性 間の相対的重要度を表わしていると考える. しかし, 個 人が考慮する選択肢数が少ない場合には， $\tilde{\theta}_{i}$ の安定性が 問題となるが, この点に関しては後述する適用事例の中 でさらに検討を行う.

次に各選択肢より得られる効用をすべて正とするた め, 一般性を失うことなくその值が大きいほど効用が増 大するように各属性の值を基準化する．たとえば所要時 間や費用といった属性は，その值が小さいほど全体の効 用が大きくなるため，次式のように変換する.

$$
X_{i j}{ }^{\prime}=1-X_{i j} / \max _{j}\left\{X_{i j}\right\}
$$

ここに, $X_{i j}{ }^{\prime}:$ 属性 $i$, 選択肢 $j$ の基準化後の值 $X_{i j}$ : 属性 $i$, 選択肢 $j$ の設定值（調査值） 式(12)による属性の基準化の目的は, 第 1 にパラメー タ一の符号の基準を統一し, 計算上の処理を容易にする ことであり，第 2 は各属性の最大值を 1 以下にすること によりパラメーターを求める際に解の発散を防止するこ とにある.ただし, 式(12)における $\max \left(X_{i j}\right)$ は, モデル 作成時の值であるため, 予測時においては $X_{i j}{ }^{\prime}$ が 1 以上 になることもある．また，符号の統一は必ずしも行う必 要はなく, その場合は, $X_{i j}{ }^{\prime}=X_{i j} / \max \left(X_{i j}\right)$ となる.

式(12)より各属性の値を決定しても, 必ずしもすべて のパラメーターが正になる保証はない. たとえばある属 性の值が大きいほど，選択肢の序列が低い場合には，そ のパラメーターは負になることがある.これは個人が提
示されたすべての属性を同時に考慮して序列を付けてい るものではないと考えることにより，パラメーター $\theta$ の 値が負である場合には，個人はその属性を考慮していな いものと判断し削除する。このように属性を絞り込むこ とにより，複数の属性が残った場合は，その意思決定基

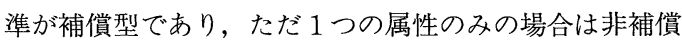
型と考えることもできる.

\section{（4）選択の深さの問題}

提示した選択肢に対して，個人は自己の意思決定基準 に基づいて序列を付けるわけであるが，その数（式(1) の n)が多くなるとノイズが入り, 精度が下がる場合があ る.ここでいうノイズとは，各属性より得られる効用の 大きさと選択肢の序列の間の関係に規則性が認められな い状態であり，これは序列の高い方の選択肢よりは，む しろ低い方の選択肢の誤判断による影響が大きい.これ は個人により異なるため，収集した序列デー夕の深さを 何らかの基準により決定する必要がある．田中 ${ }^{17)}$ の研究 によると非集計 Conjoint-Logit モデルの結果ではある が，選択肢の深さとパラメーターの分散との関係より 6 ないし 7 程度の深さは必要であるとしている．また有効 な深さの数を統計的に求める方法が Chapman ら ${ }^{13)}$ よって提案されている. それによると種々の深さ $(n=2$, $3, \cdots, E)$ における Logit モデルの尤度值を求め, その值が 急激に減少し始めたときにノイズを含む選択肢が入り込 んでいると判断している.さらにパラメーター $\theta$ の值が $\theta(E)$ と $\theta(E+1)$ に差があるかを $\chi^{2}$ 検定により統計的 な処理を行なっている。つまり式 $(5) よ り$

$$
L=\frac{e^{\omega V_{1}}}{e^{\omega V_{1}}+\cdots+e^{\omega V_{E}}} \cdot \frac{e^{\omega V_{n}}}{e^{\omega V_{2}}+\cdots+e^{\omega V_{E}}} \cdots \frac{e^{\omega V_{E}}}{e^{\omega V_{E}}}
$$

となる。式(13) は得られた序列デー夕において深さ $(E$ +1) 以後の選択肢を無視するものであり，これは序列の 深い選択肢に対する信頼性が低いという前提によるもの である。

\section{（5）Conjoint-Logit モデルによる予測の問題}

図一 1 は，個人デー夕の収集から予測までの作業フ ローを表わしている．集計モデルは，始めにデータの集 計化を行い，その集計されたデー夕を用い予測式のパラ メータ一の推定を行う. 次に将来の母集団の分布を予測 式に代入することにより，将来のシェアの計算を実施す る. 非集計モデルの場合には, セグメント別にパラメー ターを推定する必要があるため, 始めに何らかの情報に より個人データのセグメント化を行う。この場合のセグ メントの目的としては, 将来推計を行う際の外生要因の 同時分布を得る必要上と, その予測精度を確保するため のセグメントの均質化が大きな目的となる.

一般的にセグメントのための基準としては個人属性が 用いられることが多い. つまり，意思決定基準ができる 


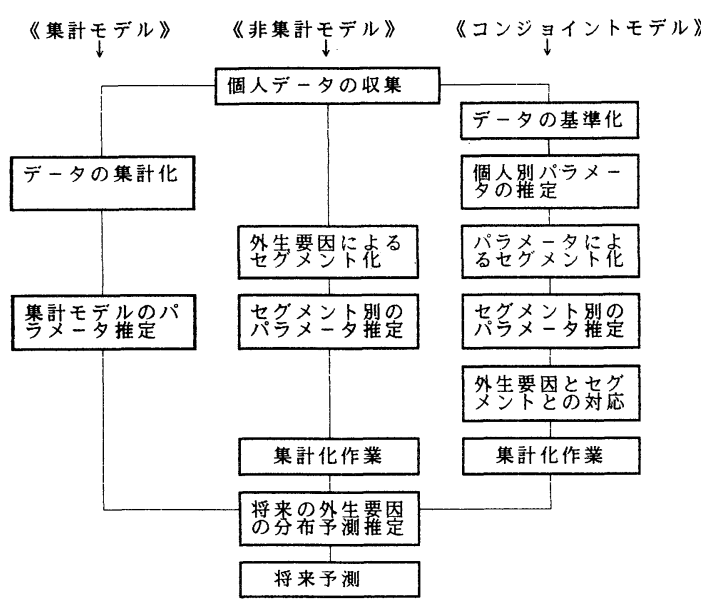

図一 1 コンジョイント分析の予測手順

だけ均質化するように個人属性を用いてセグメント化 し，セグメント別のパラメーターを推定，そして将来の 個人属性の分布を代入することにより予測を行うという ものである。しかし，七グメント化の目的が意思決定の 均質化であるが，個人属性による方法が必ずしも最良で あるという保証はない.

コンジョイント分析の予測手順は, 収集された個人 データより始めにデータの基準化（式(12)）を行い，次 に個人別のパラメーターを推定し，その結果を用いて何 らかの方法（詳しくは後述する）によりセグメント化を 行い, 次いでセグメント別のパラメーターの推定を行う. この場合, Conjoint-Logit モデルを用いてセグメント別 のパラメーターを推定するためには，非集計 Conjoint -Logit モデルを定式化する必要があるが, この点に関し ては参考文献》に詳しく記述されているので，ここでは そのためのデー夕作成についての検討を行う。つまり, Conjoint-Logit モデルにより個人別のパラメーターを 推定する際，その符号が負の場合は対応する属性を考慮 していないものとして削除することはすでに述べた。し たがって非集計 Conjoint-Logit モデルのパラメーター 推定は，個人別の基準化データを直接使用するのではな く, 個人別に絞り込まれた属性のみのデータを使用し, セグメント別のパラメーターを推定することになる。こ の点が従来の非集計 Logit モデルと大きく異なる点の 1つでもある．次にセグメントの方法について述べる。 セグメント化の目的は前述したように，予測にあたっ てはセグメント別に外生要因の同時分布が与えられるの が一般的であり，そのためにできるだけ均質な消費者グ ループを構成する必要がある，問題は “均質な消費者グ ループををどのように決定するかであり，方法論的には 2 つの方法が考えられる.1つは非集計モデルのように，
個人の社会経済特性，地域特性，トリップ特性等のよう に外生的にその基準を決定するものである。しかしこの 方法によるセグメンテーションが必ずしも “均質な消費 者グループ”を構成するという保証はない。もう1つの 方法は，べネフィット・セグメンテーションといわれる 方法で, 個人の選好構造に関して類似したサンプルを集 め，セグメントを構成しようとするものである．本研究 では後者の方法, つまり個人の効用関数（式 $(2))$ のパ ラメーターを基準として，その值の類似している個人を 集計することによりセグメント化を行う方法を考える.

個人のパラメーターを基準としてセグメント化を行う 方法として考えられるのがクラスター分析である。つま クサンプル間の類似度としてパラメーターの值を用い, 階層型のクラスター分析の適用を図るものである。 セグ メンテーションにクラスター分析を適用する場合の問題 点としては, クラスタ一数の打ち切り基準の問題と, ク ラスター分析により “均質な消費者グループ”を抽出で きるかにある，前者の問題点に関し片平 ${ }^{18}$ は， AIC 基準 に基づく方法を提案しているが，さらに今後の実証的研 究に待つところも大きいと指摘して扔り, 本論文でもこ の点に関しては今後の課題でもあるが, 一般的には総サ ンプル数の制約によるところが大きいものと考えられ る.後者の問題としては, 個人のパラメーターをメトリッ クなものとしてクラスター分析を適用した場合, 次のよ

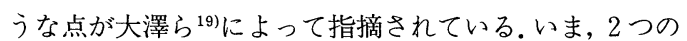
属性があり，個人 $\mathrm{A} ， \mathrm{~B}, \mathrm{C}$ のそれぞれのパラメーターが $(0.6,0.2)(0.2,0.6)(1.0,9.0)$ とすると, A, B, $\mathrm{C}$ の互いのユークリッド距離は

$$
\begin{aligned}
& d(A, B)=\sqrt{(0.6-0.2)^{2}+(0.2-0.6)^{2}}=0.566 \\
& d(B, C)=\sqrt{(0.2-1.0)^{2}+(0.6-9.0)^{2}}=8.438 \\
& d(C, A)=\sqrt{(1.0-0.6)^{2}+(9.0-0.2)^{2}}=8.809
\end{aligned}
$$

となり, 最初に $A$ と $B$ がクラスターリングされる.しか し，パラメーターの性質から考えると本来は $B$ と $C$ が 同じセグメントに属することが望ましいことがわかる.

本論文では，以上の問題点を考慮して次に示すような ヒューリスティックな方法を採用する，いま，例として 属性数を 3 ，おのおののパラメーターの值を 0 または 1 とした場合，すべての組合せとして表一1に示すような 7 通りの軸を考える。

表一 1 で軸 1 は，属性 1 のみを考慮しているセグメン トであり, 軸 3 は属性 1 属性 2 を, 軸 7 はすべての属性 の影響を考慮したセグメントを構成していると考える.

\section{表一1 パラメーターの組合せ}

\begin{tabular}{|c|c|c|c|c|c|c|c|}
\hline 属性】軸 & 1 & 2 & 3 & 4 & 5 & 6 & 7 \\
\hline 1 & 1 & 0 & 1 & 0 & 1 & 0 & 1 \\
\hline 2 & 0 & 1 & 1 & 0 & 0 & 1 & 1 \\
\hline 3 & 0 & 0 & 0 & 1 & 1 & 1 & 1 \\
\hline
\end{tabular}


したがって，与えられた属性数よりあらかじめ表一 1 に 相当するものを作成しておき，求められた個人のパラ メーターの值を空間座標とし, 各座標から表一 1 の各軸 (セグメント)へ写像した場合, 最も近い軸がそのサンプ ルの所属するセグメントとする. しかし，属性数が多く なると始めに割りつけるべき軸の数が多くなり，かつ 1 軸当たりのサンプル数が減少することが考えられる．そ の場合は最寄りの軸を統合することにより，セグメント 数と各セグメント内のサンプル数を決定する.

ベネフィット・セグメンテーションは，外生要因によ るセグメンテーションよりも・“均質な消費者グループ” を構成する可能性は高いが, 予測にあたっては外生要因 との対応が問題となるため, 実際にはその点についての 検討が必要となる。

\section{Conjoint-Logit モデルの交通機関選択へ の適用例}

\section{（1）調査の概要}

Conjoint-Logit モデルによる適用事例としては, 通 勤・通学時における交通機関選択問題を取り上げる. 特 に本節の事例研究では, Conjoint-Logit モデルの予測精 度についての検討を重点的に行うことを目的とするた め, 選択肢の深さの問題やセグメント化の問題について は今後の実証的研究の中でさらに検討を行う必要があ る.モデル作成のためのデー夕収集対象地域としては, 仙台市地下鉄南北線沿線の住宅地を選定した。その理由
としては，次の 2 点が挙げられる.

(1) 交通機関として新たに地下鉄が加わったため，選 択肢の数が増加した。

(2) 地下鉄開業前の利用可能な交通手段より, Conjoint-Logit モデルを構築し, 開通後の交通手段の予 測が行える.

特に 2 番目の予測精度の問題に対しては, 従来の非集 計 Logit モデルとの比較も容易に行えるため, Conjoint -Logit モデルの有効性を検討するうえでも重要な理由 である．調查項目としては，交通目的，個人属性等，従 来の調查形式と同様であるが，調査の目的が個人の交通 手段の組合せの選好順位を求めることであるため，表 ー 2 のような調查票を作成した。 なお，調查は平成元年 4 月に訪問留置調查により実施, 総配布数は 800 枚であ $\eta$, 回収数は 615 枚（回収率 $76.9 \%$ ）であった。回収し た調査票の中から，選択肢数が 2 以上のもの，および地 下鉄開通前後で目的地の変化がないものを選定した結 果, 385 枚の調査票が残った. さらにその中からすべての 項目が記入されているものは 300 であったため，以下の 計算に用いた総サンプル数は 300 である。

表一2 からもわかるように利用可能な交通手段の組合 せにすべて○を付け（調査票に記入以外の組合せがある 場合は，空欄に記入)，次にそれらに序列を記入し，さら に属性の值を各手段別に記入してもらった. そして最後 に，地下鉄が開業する以前に利用していた交通手段，お よび $\omega_{c}$ の計算のために，潜在的な選択確率を記入して もらった，その結果，最終的には表 ー 3 に示すように 12 の選択肢を設 定，またモデル作成のための属性と しては以下に示すものを採用した。

(1) 全所要時間

(2) 徒歩時間

(3) 待ち時間

(4) 乗り変之回数

(5) 自己負担の費用

(6) 名ミ一変数

(2)はアクセス・イグレス時間の合 計であり，6のダミ一変数は表一 3 の二輪車のみの使用とその他の交通 機関の組合せでは，その交通特性が 異なるため，二輪車のみの利用の場 合は 1 ，それ以外は 0 とした。また， Conjoint-Logit モデルも非集計 Logit モデルと同様な変数を取り込 むことが可能であるが，選択肢数の 制約により属性数を多くすることに は問題がある。 
表一 3 交通手段の選択肢

\begin{tabular}{|c|c|c|c|}
\hline No & 交通機関の組み合わせ & No & 交通機関の組み合わせ \\
\hline 1 & 二輪車（自転車又はバイク） & 7 & パス+地下鉄 \\
\hline 2 & 車 & 8 & 二輪車 +地下鉄 +バス \\
\hline 3 & バス（又はバス+バス） & 9 & $\mathrm{JR+バス}$ \\
\hline 4 & 地下鉄 & 10 & 地下鉄 + J R \\
\hline 5 & 二輪車＋地下鉄 & 11 & バス+地下鉄 $+\mathrm{J} \mathrm{R}$ \\
\hline 6 & 車十地下鉄 & 12 & 車十地下鉄 $+J R$ \\
\hline
\end{tabular}

次に Conjoint-Logit モデルの有効性を検討するため, 以下に示す 2 点についての検証を行った.

(1) Conjoint-Logit モデルの現状再現性と予測精度 の検討

(2) 非集計 Conjoint-Logit モデルの各種統計的検定 と予測精度の検討

上記の予測精度の検討においては, 総サンプル 300 の 中から, 地下鉄開業前に 2 つ以上の利用可能交通手段が あり，かつ開業後に地下鉄を含む交通手段の組合せが 1 つ以上あるサンプルを抽出し (サンプル数 139), 開業前 のデータでパラメーターを推定し，その結果に開業後の デー夕を適用し，利用交通手段を推定する．そして実際 の交通手段と一致しているかを点検するものである．ち なみに地下鉄開業前後における機関分担は，車のみの利 用が開業前に $53.3 \%$, 開業後が $54.0 \%$ とほとんど変化は みられない。またバスのみの利用は開業前が $32.9 \%$, 開 業後が $13.0 \%$ と大幅に減少し，その減少分が地下鉄（ま たは地下鉄との組合せ）への転換（17.7\%）となってい る。

\section{（2）個人別のパラメーターの推定}

表一 4の（a）は収集された個人データを，(b)は式(12) により基準化された属性の值を表わしている.さらに(c) は式(11)により個人別のパラメーターを推定した結果 と，そのときの最終的な属性の值を記入してある.ここ で費用の属性は結果的にパラメーターが負となったため 削除されている．また各選択肢の効用值は完全にその序 列を再現していることがわかる．以上のようにしてすべ てのサンプル別のパラメーターを求めることができる が，選択肢の深さが増加すると完全にその序列を再現す ることが困難となる．図一 2 は選択肢の深さとその比率 を，図一 3 は選択肢の深さとノイズの関係を表わしてい る.ここでノイズとは, 式(11)より求められた効用が $V_{1}$ $>V_{2}>\cdots V_{n}$ と完全にその序列を再現していない場合， つまり $V_{i}<V_{i+1}$ が 1 か所以上存在する場合をノイズあ りとしている. 選択肢の梁さは 4 までで全体の $92 \%$ 占 めており，交通機関の選択においてはそれほどの梁さを 期待することはできないことがわかる.また図一 3 より， 深さが 2 の場合は当然ノイズはないが, 深さが増すに従 いノイズが増加する傾向にある. 最後に予測精度の検証 として地下鉄開業前のデータで個人別パラメーターを推
定し，開通後の手段予測を行い，実際に選択した結果と の対応を検討した結果, 139 サンプル中 137 サンプル(適 中率 $98.6 \%$ ）が適中し, 非常に高い值となった。

(3) 非集計 Conjoint-Logit モデルの検討

Conjoint-Logit モデルは, 選択肢数が増加するに従 い，ノイズが入ることが判明したが，予測精度の面では 十分満足する結果となった．しかしこれだけでは Conjoint-Logit モデルの有効性が確認できないため, 非集計 Conjoint-Logit モデルの統計的性質を利用し，その有効 性の検討を行う.

表一 5 は，モデルの現状再現性を確認するため, 各属 性の $t$-値, $\rho^{2}$ 值, および適中率を示している.ケース 1 とケース 2 は非集計 Conjoint-Logit モデルによる結果 を，ケース 3 は，非集計 Logit モデルによる結果を表わ している，ただし，いずれもセグメント数は 1 (つまり セグメント化を行わない）の状態である.ここでケース 1 は, 式 $(9)$ よりあらがめ求められた個人別の $\omega_{0}$ の 值を用い, 式(11) と同様に $\sum_{i} \tilde{\theta}_{i}{ }^{2}=1$ の制約下での結果で あり，ケース 2 は非集計 Logit モデルと同じく $\omega=1$ と してパラメーター $\theta$ を推定したものである.したがっ て，ケース 1, ケース 2 のパラメーターは全サンプル共 通であるが，ケース 1 の場合は， $\omega$ の值が個人により異 なっており，個人差を考慮した非集計 Conjoint-Logit モ

\section{表一 4 個人別のパラメーター推定手順}

(a) 収集された個人デー夕

\begin{tabular}{|c|c|c|c|c|c|c|}
\hline 選択順位 & 䌊晆間 & 徒㱑時間 & 恃壱時 & 司乗換回 & 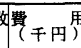 & 用 $タ ミ ー$ \\
\hline 車 & 40 & 0 & 0 & 0 & 6 & 0 \\
\hline バス十地下鉄 & 70 & 20 & 10 & 3 & 0 & 0 \\
\hline パ ス & 90 & 15 & 10 & 2 & 0 & 0 \\
\hline
\end{tabular}

（b）式(12)により基準化後のテータ

\begin{tabular}{|c|c|c|c|c|c|c|}
\hline 選択順位 & 䌊時間 & 徒歩時間 & 待ち時間 & 乗換 回 & & 用タミ- \\
\hline 車 & 0.556 & 1.000 & 1.000 & 1.000 & 0.0 & 0.0 \\
\hline バス +地下鉄 & 0.222 & 0.0 & 0.0 & 0.0 & 1.0 & 0.0 \\
\hline バ ス & 0.0 & 0.250 & 0.0 & 0.333 & 1.0 & 0.0 \\
\hline
\end{tabular}

(c) Conjoint-Logitモデルに用いた最終データと推定パラメータ

\begin{tabular}{|c|l|l|l|l|l|l|l|}
\hline 選択順位 & 䌊時間 & 徒歩時間特ち時間乗換回数費 & 用タミー & 効 用 \\
\hline 車 & 0.556 & 1.000 & 1.000 & 1.000 & - & 0.0 & 1.308 \\
\hline バス+地下鉄 & 0.222 & 0.0 & 0.0 & 0.0 & - & 0.0 & 0.152 \\
\hline バ ス & 0.0 & 0.250 & 0.0 & 0.333 & - & 0.0 & 0.052 \\
\hline パラメータ & 0.683 & 0.197 & 0.702 & 0.029 & - & 0.0 & \\
\hline
\end{tabular}
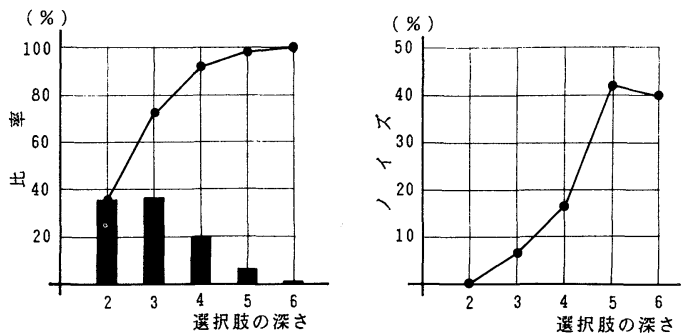

図一2 選択肢の深さ 
表一5 各非集計モデルの現状再現性

\begin{tabular}{|c|c|c|c|}
\hline 属 性 & ケース 1 & ケース2 & ケース3 \\
\hline 総時間 & $0.677(8.062)$ & $6.459(9.381)$ & $6.705(7.902)$ \\
\hline 徒歩時間 & $0.269(5.014)$ & $2.163(5.981)$ & $1.746(3.795)$ \\
\hline 待ち時間 & $0.142(2.968)$ & $1.220(3.409)$ & $0.638(1.333)$ \\
\hline 乗換回数 & $0.258(6.095)$ & $2.066(6.710)$ & $1.252(3.454)$ \\
\hline 費 用 & $0.313(5.186)$ & $3.460(7.272)$ & $2.097(4.681)$ \\
\hline タミ- & $0.534(8.774)$ & $5.545(9.921)$ & $2.156(5.676)$ \\
\hline サソプ日 数 & 300 & 300 & 300 \\
\hline$\rho^{2}$ 值 & 0.450 & 0.635 & 0.619 \\
\hline 畺中率 & $99.3 \%$ & $99.3 \%$ & $84.7 \%$ \\
\hline
\end{tabular}

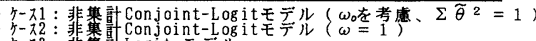
( $)$; 韭 $\mathrm{t} t$ - 值

\section{表一 6 各非集計モデルの予測精度}

\begin{tabular}{|c|c|c|c|}
\hline 属 性 & ケ-ス1 & ケース2 & ケース 3 \\
\hline 释時間 & $0.680(4.125)$ & $5.821(3.216)$ & $6.090(4.629)$ \\
\hline 徒步時間 & $0.201(1.571)$ & $2.478(2.419)$ & $1.106(1.656)$ \\
\hline 持ち時間 & $0.333(2.356)$ & $4.009(3.082)$ & $0.202(0.297)$ \\
\hline 乗換回数 & $0.146(0.773)$ & $0.136(0.110)$ & $1.241(1.449)$ \\
\hline 費 用 & $0.358(3.221)$ & $4.603(3.738)$ & $2.253(3.768)$ \\
\hline タミ- & $0.487(5.332)$ & $6.459(4.782)$ & $2.194(4.486)$ \\
\hline サソプル 数 & 139 & 139 & 139 \\
\hline$\rho^{2}$ 值 & 0.627 & 0.810 & 0.532 \\
\hline 通中率 & $99.3 \%$ & $95.7 \%$ & $79.9 \%$ \\
\hline
\end{tabular}

デルとなっている.

表一 5 より明らかなように $\rho^{2}$ 值を除けばすべての属 性の $t$-值および啇中率も非集計 Conjoint-Logit モデル の方が高いことがわかる. 特に適中率に関しては, ケー ス 1 ，ケース 2 とも 300 サンプル中䛊判断が 2 サンプル しかなく, 非常に現状再現性が高い結果となっている.

さらにこれらの各モデルの予測精度を確認するため に, 前述した 139 サンプルに対し, 地下鉄開業前のデー タでパラメーターを推定し, 開業後のデータを用いその 予測精度を求めたものが表一 6 である. 表一 6 も表一 5 と同様に非集計 Conjoint-Logit モデルの精度は, 非集計 Logit モデルに比較して高く, 特に適中率に着目すると, ケース 1 の $99.3 \%$ ( 1 サンプルだけ誤判断), ケース 2 の 95.7\%と非集計 Logit モデル（ケース 3 ）の 79.9\%に比 較して非常に高い結果となっている．また，個人別の $\omega_{0}$ の值を考慮したケース 1 の適中率がケース 2 より予測精 度が高い結果となっており，これからも $\omega$ を考慮する必 要があることがわかる. ただし, 表一 5 , 表一 6 ともケー ス 1 に比較してケース 2 の方の $\rho^{2}$ 值がいずれも高い值 となっている.これはケース 1 において個人別の $\omega_{0}$ の 平均值が 4.6 であり，式(11)に示したように条件付最大 化問題となっていることによるものである. したがって 本論文では適中率の值をもって評価を行った。

このように非集計 Conjoint-Logit モデルの現状再現 性,およびその予測性が高い理由として考えられるのは, その前段階において Conjoint-Logit モデルにより個人 ごとにパラメーターが負になる属性のデー夕はあらかじ
め削除してあり (表一 4 (c) 参照)，この点が非集計 Logit モデルのデータ構造との違いの 1 つでもある。

しかし, Conjoint-Logit モデルを交通機関選択モデル へ適用して，いくつかの問題点も明らかとなった．特に パラメーターの符号による属性の削除と予測精度の問題 である.つまり Conjoint-Logit モデルは， $\theta_{i}$ の特異な動 きを基準化後の $\tilde{\theta}_{i}$ ではなく， $\omega_{0}$ に帰することにより $\tilde{\theta}_{i}$ の符号を基準に個人ごとに属性の削除を行っている。こ れは個人ごとに求められたパラメーターの符号と全体効 用との間に生じる論理的矛盾を回避するための処理であ る.しかし，一般的に選択肢数が求めるべきパラメーター 数より少ない場合には, 推定されるパラメーターには自 由度がなく, 求められたパラメーターの信頼性が問題と なる．この属性の削除の処理の妥当性に関しては，個人 ごとに得られる序列データを繰り返し収集し, 少なくと もパラメーター数より多い（理論的にはパラメーター 数十 1 以上）序列データを用いる必要がある.そのため の方法として考えられるのが実験計画法を用いた序列 データの収集や，一対比較法による方法である.これは $\mathrm{SP}$ データの信頼性の問題もからんでくるため, 適切な デー夕収集を計画する必要がある，その結果，得られた デー夕量がたとえ統計的処理に耐え得るもので，かつパ ラメーターの統計量が基準を満足していても, 必ずしも パラメーターの符号と全体効用の間に矛盾が生じないと はい之ない.したがって，属性の削除の問題の妥当性に 関しては，実際の予測への適用において議論されるべき ものであり，この点に関し，本研究の事例から限定的で はあるが，その妥当性は十分あるものと考えられる。

次に予測精度の問題であるが, 非集計 Conjoint-Logit モデルは, サンプル中の個人については Conjoint-Logit モデルを適用することにより，その評価構造（個人ごと に考慮している属性）に関する情報を得ているため, 予 測におろいてもそのまま個人の情報を適用できるが，一般 的な予測（母集団への拡張）においては，個人の評価構 造に関する情報が欠けているため，何らかの方法で推定 する必要がある，その方法として考えられるのが図一 1 に示したように外生要因とセグメントとの対応である. したがって，予測精度の議論を行うためには，一般的な 母集団への拡張後における結果との比較検討を行う必要 がある、ただし，交通条件の変化による選択肢間の相詨 的変化の検討や, 得られたサンプルがランダムでかつ母 集団を代表するに十分なる量を有している場合には，収 集したサンプルのみで各種の政策評価が実施可能なた め, 必ずしも外生要因との対応は必要ではなく，本研究 で提案している個人モデルは有効な手段となるものと考 えられる。 


\section{5 . 結論と今後の課題}

本論文は，個人の意思決定の分析手法の 1 つであるコ ンジョイント分析を取り上げ，それを交通手段選択問題 へ適用する場合の問題点の検討と，実証的検証を踏まえ て Conjoint-Logit モデルの有効性について述べたもの であり，得られた主な結論は以下のとおりである。

（1）Conjoint-Logit モデルにより個人の意思決定 基準が補償型か, 非補償型かを評価することが可能であ る.

（2）また，非集計 Logit モデルで問題となっている 個人間の意思決定基準の差を直接評価することが可能で ある。

（3）Conjoint-Logit モデルは，個人の特性がパラ メーターに直接表現されていると考えられるため，個人 属性を取り込む必要はなく，すべてサービス変数のみで モデルの構築ができる．また，個人モデルゆえにサンプ 儿数の制限を受けないという大きな特徴がある.

（4）Conjoint-Logit モデルの問題の 1 つである「解 の不定性」に対して，個人の選択確率を考慮することに より解決できることを示した。

（5）非集計 Conjoint-Logit モデルの現状再現性, お よびその予測性は従来のモデルに比較して非常に高い精 度を有していることを明らかにした。

しかし，また多くの問題点も明らかになった，特に選 択肢の深さとパラメーターの安定性との関係，予測にお ける個人情報の不足等である。 また Logit モデル特有の IIA 特性の問題もある. 特に本研究の事例で採用した選 択肢の大部分がマストラとの組合せであるような場合に は, NL モデル等の導入も検討する必要がある.これらの 問題点に関しては，さらに理論的・実証的研究を進める 必要があるが, コンジョイント分析により得られる個人 情報の特性を生かした意思決定問題の開発を進めるうえ で，本研究の意義があるものと確信している。

最後に本論文の査読を担当していただいた先生方には 適切かつ重要なご指摘を多数いただいた。ここに記して 謝意を表する。

\section{参 考 文 献}

1）近藤次郎：意思決定の方法, NHK ブックス, 1985.6.

2）黒川 洸：非集計行動モデルの意義と現状，土木計画学 講習会テキスト，No.15，pp. $1 〜 8 ， 1984.11$.

3）太田勝敏：非集計行動モデルの理論展開，土木計画学講 習会テキス卜，No. 15 , pp. 9〜23，1984.11.
4）佐藤・五十嵐：空港アクセスにおける交通機関別分担モ デルの作成, 土木学会論文報告集, No. 274, pp.95 104, 1978.6.

5）河上・広畠：利用者の主観的評洒を考慮した非集計交通 手段選択モデル，土木学会論文集，No. 353，pp.83～92， 1985.1.

6) Ben-Akiva and Morikawa, T.: Estimation of Mode Switching Models from Revealed Preferences and Stated Intention Prepared for the International Conference on Dynamic Travel Behavior Analysis, Kyoto, 1989

7）小川孔輔：「コンジョイント尺度」を与える最尤推定量 について, 経営志林, Vol. 18, pp.37〜 52, 1981.

8) Kruskal, J.B. : Analysis of Factorial Experiments by Estimating Monotone Transformations of the Data, Journal of Royal Statistical Society, B-27, pp.251 $\sim 263,1965$.

9) Srinivasan, V. and Shocker, A.D. : Estimating the Weighs for Multiple Atributes in a Composite Criterion Using Pairwise Judgments, PSYCHOMETRIKA, Vol. 38, No. 4, pp.473 493, 1973.12.

10）片平秀貴：多属性消費者選択モデル，経済学論集，Vol. 50, No. 2 , pp. $2 \sim 18,1984.7$.

11) Ogawa, K.: An Approach to Simultaneous Estimation and Segmentation in Conjoint Analysis, Marketing Science, Vol. 6, No. 1, pp.66 81, 1987.

12) McFadden, D.: The Choice Theory Approach to Market Research, Marketing Science, Vol. 5, No.4, pp.275 297, 1986

13) Chapman, R.G. and Staelin, R. : Exploiting Rank Ordered Choice Set Data Within the Stochastic Utility Model, Journal of Marketing Research, Vol. XIX, pp.288 301, 1982.9 .

14）島崎・上川・松本：判断基準の序列にもとづく交通機関 選択モデル, 土木計画学研究·論文集, No. 5, pp.59〜66, 1987.11.

15）片平秀貴：マーケッティング・サイエンス, 東京大学出 版会, 1987.4 .

16）藤原・杉恵・平野：順序づけした意識デー夕の適用例に 関する研究, 土木計画学研究・講演集, No. 11, pp. 699 706, 1988.11.

17）田中克明：確率的コンジョイントモデルの諸問題，大阪 大学経済学, Vol. 36, No. 12, pp.40 50, 1986.9.

18）片平秀貴 : 離散的選好モデルと選好の異質性，経済学論 集, No. 53-3, pp.31 45, 1987.10.

19）大澤・片平・野本：消費者研究における単調変換法を用 いたコンジョイント測定法の応用に関する問願点，大阪 大学経済学, Vol. 30, No. 2.3, pp.243 262, 1980.12.

(1989.5.22・受付) 